\title{
Leaf orientation of maize plants as influenced by seed positioning in the soil
}

\section{Orientação foliar de plantas milho influenciada pelo posicionamento da semente no solo}

\author{
Osvaldo Matsuo ${ }^{1}$; Otávio Jorge Grigoli Abi Saab²; \\ André Prechlak Barbosa ${ }^{3}$; Luiz Abilio Ribeiro Alves ${ }^{4}$; Claudemir Zucareli ${ }^{2}$
}

\begin{abstract}
Highlights:
Laying the seed vertically pointing down provides a favorable orientation. Laying the seed horizontally on the dorsal face provides a favorable orientation. The embryo should be in the perpendicular orientation for its natural emergence. The orientation of maize plants is independent of seed shape.

The orientation of maize plants varies according to seed positioning.
\end{abstract}

\begin{abstract}
Adequate positioning of the seed in the planting furrow allows the maize leaves to be oriented perpendicularly in relation to the sowing row, minimizing overlap and self-shading. The aim of this study was to investigate the positioning of flat and round maize seeds in the furrow and its effects on leaf orientation and plant architecture in the horizontal plane. The experiment was conducted in pots in a greenhouse, using 20C-sieve (flat) and 22R-sieve (round) seeds of the Balu 280 PRO hybrid, at a sowing depth of $0.04 \mathrm{~m}$. The experiment was laid out in a completely randomized design with a $5 \times 2$ factorial arrangement [five seed positions and two shapes (flat and round)] with eight replicates, totaling 80 plots. Leaf orientation was evaluated at the V3 stage. Seed size and shape did not show a significant interaction with seed positioning, suggesting that maize leaf orientation was only influenced by seed positioning. The treatments involving seeds laid in a vertical position pointing toward the bottom of the pot and horizontally with the face that contains only the endosperm (dorsal face) down are the most favorable, regardless of seed shape.
\end{abstract}

Key words: Zea mays. Seed deposition. Flat seeds. Round seeds. Plant architecture.

\section{Resumo}

O adequado posicionamento da semente de milho no sulco pode possibilitar a orientação perpendicular das folhas em relação à linha de semeadura, minimizando sobreposição e auto sombreamento. O objetivo deste estudo foi avaliar o posicionamento de sementes de milho chata e redonda no sulco de semeadura e os seus efeitos na orientação das folhas e na arquitetura da planta no plano horizontal. O experimento foi conduzido em vasos sob condições de casa de vegetação, sendo utilizadas sementes de peneiras

\footnotetext{
1 Discente de Doutorado, Programa de Pós-Graduação em Agronomia, Universidade Estadual de Londrina, UEL, Londrina, PR, Brasil. E-mail: tga.mats@gmail.com

2 Profs. Drs., Departamento de Agronomia, UEL, Londrina, PR, Brasil. E-mail: abisaab@uel.br; claudemircca@uel.br

3 Prof. M.e, Pontifícia Universidade Católica do Paraná, PUCPR, Toledo, PR., Brasil. E-mail: andreprechlak@gmail.com

4 Discente de Mestrado, Programa de Pós-Graduação em Agronomia, UEL, Londrina, PR, Brasil. E-mail: labilioalves@gmail.com

* Author for correspondence
} 
20C (chatas) e 22R (redondas) do híbrido Balu 280 PRO, com semeadura a 0,04 m de profundidade. $\mathrm{O}$ delineamento estatístico utilizado foi inteiramente casualizado, em esquema fatorial 5 x 2 (cinco posições da semente, dois formatos - chata e redonda) com oito repetições, totalizando 80 parcelas. A avaliação da orientação da folha foi realizada no estádio V3. O tamanho e o formato das sementes não demonstraram interação significativa com o posicionamento das sementes. Sugerindo que a orientação da folha do milho ocorreu em função do efeito da posição de sementes, sendo mais favoráveis os tratamentos na posição vertical apontada para o fundo do vaso e a posição na horizontal deitado com a face que contém somente o endosperma (dorsal) voltado para baixo, independente da forma.

Palavras-chave: Zea mays. Deposição da semente. Sementes chatas. Sementes redondas. Arquitetura da planta.

\section{Introduction}

Maize (Zea mays L.) is highlighted as one of the main crops in the world agricultural scenario due to its economic and social importance, which is a result of its varied applications that range from human and animal nutrition to the chemical, pharmaceutical, beverage and fuel industries (Regitano-D'Arce, Spoto, \& Castellucci, 2015; Sologuren, 2015).

To produce their food, plants convert luminous energy into chemical energy. Maize also stands out in this respect as typical $\mathrm{C} 4$ plant, meaning it is highly efficient in this conversion process. This process depends mainly on effective interception of photosynthetically active radiation (PAR) (Loomis \& Amthor, 1999). Management practices such as defining the arrangement of maize plants with different distribution and orientations of shapes and structures can contribute to improving its PAR interception efficiency (Argenta, Silva, \& Sangoi, 2001; Petter et al., 2016), consequently increasing grain yield (Ottman \& Welch, 1989; Kappes et al., 2010; Sangoi, Silva, \& Argenta, 2010a).

Strategic positioning of seeds in the planting furrow may allow the leaves to be oriented in the horizontal plane perpendicularly to the sowing row, which would reduce leaf overlap (shading) and thus increase PAR interception and grain yield (Fortin \& Pierce, 1996; Toler, Murdock, Stapleton, \& Wallace, 1999; Torres, Vossenkemper, Raun, \& Taylor, 2011; Taiz, Moller, \& Murphy, 2017; Sangoi, Ender, Guidolin, Almeida, \& Heberle, 2001).

Fortin and Pierce (1996) suggested that the random orientation of maize ear leaves is a result of random positioning of seeds in the furrow. By controlling the position of seeds, leaves can be oriented perpendicularly to the sowing row. As stated by Toler et al. (1999), this phenomenon occurs when the seed is placed vertically with the tip pointing down in the soil and the embryo facing the middle of the inter-row, which results in higher grain yields than when the seed is sown randomly. In addition to this position, Torres et al. (2011) sowed flat seeds horizontally with the dorsal face down and found this position to be beneficial for leaf orientation, as it prevented shading.

Most studies investigating leaf orientation in the horizontal plane have been conducted with flat seeds and only a few with round seeds, most likely due to the ease of sowing the former type. The morphology of the maize plant, whose leaves are inserted at the stem in an opposite, distally and bilaterally symmetrical manner (Castro, Kluge, \& Sestari, 2008), also contributes to the arrangement of plants parallel to each other and their leaves being positioned perpendicularly to the sowing row (Loomis \& Williams, 1969; Girardin, 1992; Fortin, \& Pierce, 1996; Toler et al., 1999; Torres et al., 2011). This is probably a result of the combination of the oriented position of the seed in the planting furrow coupled with the natural position of the embryonic axis (radicle, hypocotyl and the plumule) within the seed. In this situation, the germination, emergence and straight directional growth (tropism) of the embryo axis follow the length direction of the maize seed. When seeds are stimulated by environmental factors (gravitropism), the plumule grows toward the light and the radicle toward the 
lower soil layers in search for water and nutrients (Taiz et al., 2017). Together, those resources would be the main factors to enable an ordered maintenance of symmetrical bilateral growth in maize plants oriented perpendicularly to the sowing row (Loomis \& Williams 1969; Girardin, 1992; Fortin \& Pierce, 1996; Toler et al., 1999; Torres et al., 2011).

Plant breeding has provided the development of different maize hybrids adapted to the most varied agricultural regions and with high grain-yield potential due to highly dense plant arrangements (Sangoi et al., 2011; Costa et al., 2015; Uate, Von Pinho, Cancellier, Camilo, \& Bernardo, 2015; Pereira et al., 2017). Therefore, new research is warranted to evaluate high-density arrangements of maize plants in the horizontal plane (Argenta, et al., 2001; Felipe, Duarte, \& Camarano, 2010).

The present study thus proposes to examine the positioning of flat and round maize seeds in the planting furrow and its effects on leaf orientation and plant architecture in the horizontal plane.

\section{Material and Methods}

The experiment was conducted in a Vand der Hoeven greenhouse at the Center for Agrarian Sciences in the Department of Agronomy of the State University of Londrina, located in the municipality of Londrina - PR, Brazil. The greenhouse is characterized as a protected and controlled environment, with average temperature set at $25{ }^{\circ} \mathrm{C}$, air relative humidity between 65 and $70 \%$ and solar radiation incidence reduced by approximately $20 \%$.

Experimental units were represented by 80 plastic pots with the following dimensions: $10 \mathrm{~cm}$ height, $13 \mathrm{~cm}$ upper diameter and $9.5 \mathrm{~cm}$ lower diameter, making up a volume of $900 \mathrm{~mL}$. The pots were filled with soil classified as a Haplorthox, which was previously sieved to obtain a uniform particle size. Seeds of maize cultivar Balu $280 \mathrm{PRO}$, of 22-R (round) and 20-C (flat) sieve sizes, singlehybrid type, early cycle and with a semi-hard grain texture were used (Figure 1).

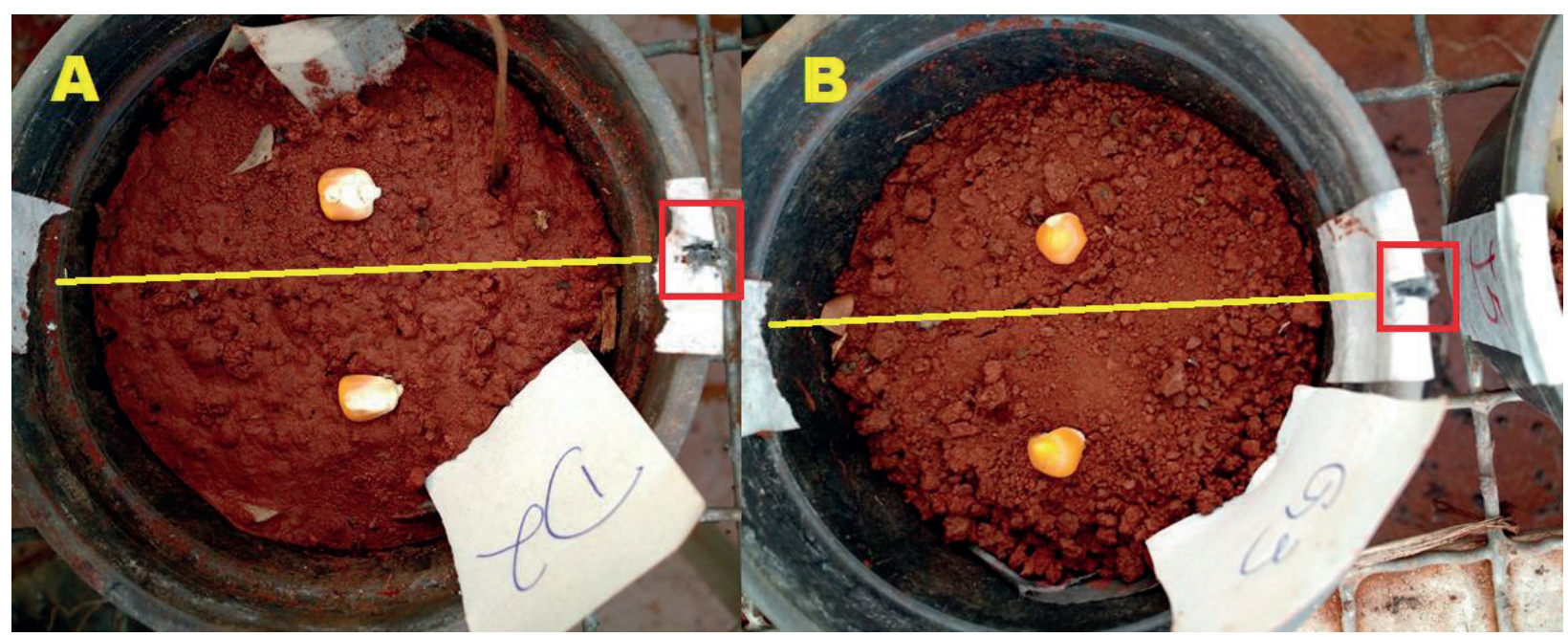

Figure 1. Flat (A) and round (B) maize seed shapes and imaginary line based on the reference marking on the border of the plastic pot. 
The experiment was laid out in a completely randomized design in a $5 \times 2$ factorial arrangement represented by five seed positions in the planting furrow and two seed shapes (flat and round sieves), with 8 replicates. As shown in Table 1, the treatments refer to the oriented positioning of the seeds in the substrate. Treatments Ar to Er are the same as Af to Ef regarding seed positioning, but differ in shape [round (r) or flat (f)]. The seeds in treatments Af and $\mathrm{Ar}, \mathrm{Bf}$ and $\mathrm{Br}$ and $\mathrm{Cf}$ and $\mathrm{Cr}$ were positioned in the substrate with the embryo face to the left of the reference marking made on the pot (Figure 1). Treatments Df and Dr and Ef and Er were sown with the seed tip pointing toward the marking on the pot. The adopted procedure was aimed at fixing the seed position to allow a better assessment of orientation.

Table 1

Treatments and respective controlled positions in the sowing of maize seeds with flat (Af to Ef) and round (Ar to Er) shapes

\begin{tabular}{ccc} 
Treatment & Seed position and orientation & $\begin{array}{c}\text { Description } \\
\text { Ff and } \mathbf{A r} \\
\text { lying on the side, tip pointing toward the marking on } \\
\text { the border of the pot. }\end{array}$ \\
Bf and $\mathbf{B r}$ & $\begin{array}{c}\text { Flat (Bf) and round (Br), vertical position, tip point- } \\
\text { ing down toward the bottom of the pot. }\end{array}$ \\
\hline Df and $\mathbf{C r}$ & $\begin{array}{c}\text { Flat (Cf) and round (Cr), vertical position, tip point- } \\
\text { ing toward soil surface. }\end{array}$ \\
\hline Ef and $\mathbf{E r}$ & $\begin{array}{c}\text { Flat (Df) and round (Dr), horizontal position, lying } \\
\text { with the dorsal face on the soil, tip pointing toward } \\
\text { the marking on the pot. }\end{array}$ \\
\hline
\end{tabular}

The substrate was placed in two steps to avoid dislocating the seed during sowing and irrigation. The first portion of substrate was placed up to a height of $2 / 3$ of the plastic pot and then moistened to improve the fixation of the seed in the position established for that treatment. After this procedure, the remaining substrate was placed until the seed was positioned at a depth of only $4 \mathrm{~cm}$, using two seeds per pot. Irrigation was performed manually so as to maintain substrate moisture. After seedling emergence, the plants were thinned, leaving one plant per pot.

The angles that determine the orientation of maize plants in the horizontal plane were measured in the V3 vegetative stage, at the third fully expanded leaf (Ritchie \& Hanway, 1989), via digital image 
analysis. The images were capture using a Sony Cybershot 16 MP digital camera fixed on a tripod and then framed by the top of each plant canopy and centralized in the center of the plant a region named whorl. A marking was made passing through the center of the plastic pot to be taken as reference (Figure 2). AutoCad software (Autodesk, 2014) was used for the digital processing of the images, where the leaf angle of the plant in the horizontal plane was determined relative to the reference marking.

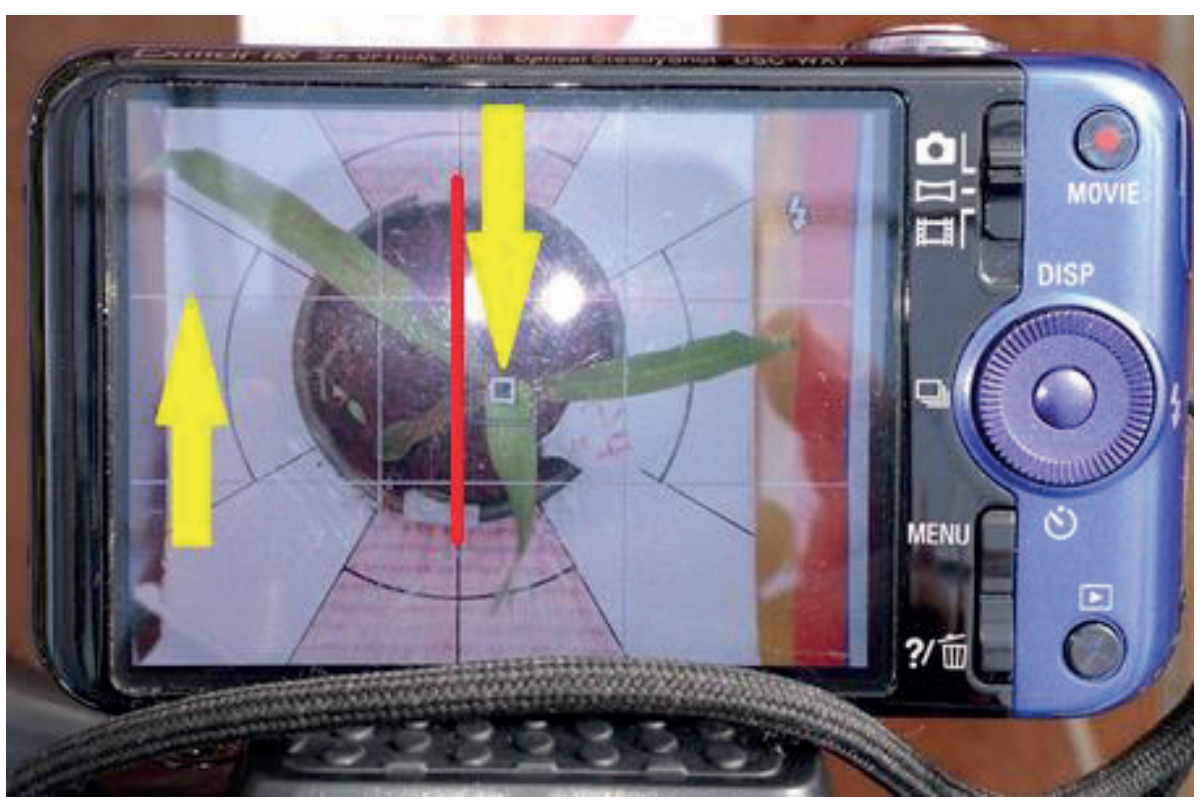

Figure 2. Images captured by the digital camera with grid framing on the display. Use of camera "central focus" tool, centering on the maize whorl, and marking in the center of the pot.

The measurement at the third expanded leaf of the plant maize was performed by tracing virtual lines representing the " $\mathrm{X}$ " and " $\mathrm{Y}$ " axes on the top of the plant, thus dividing the image into quadrants. Using appropriate tools of the software, a straight line was traced and fixed from the center of the whorl, on the central nerve of the third leave, with the angle established between the line traced on the leaf and the virtual " $X$ " axis. In the evaluation of the orientation of the third leaf of the maize plant, the first quadrant $\left(0^{\circ}\right.$ to $\left.90^{\circ}\right)$ was considered the base for angle reading. Angle measurements of leaves which developed in the other quadrants (between $91^{\circ}$ and $360^{\circ}$ ) were corrected for the values equivalent to the first quadrant by subtracting the quadrant in which it was present. In this way, the data referring to angles were tabulated only in the range of $0^{\circ}$ to $90^{\circ}$ (Figure $3)$. The angles were stratified into classes, allowing a differentiation of the orientations into a greater or lower possibility of overlap and self-shading in the maize leaves. 


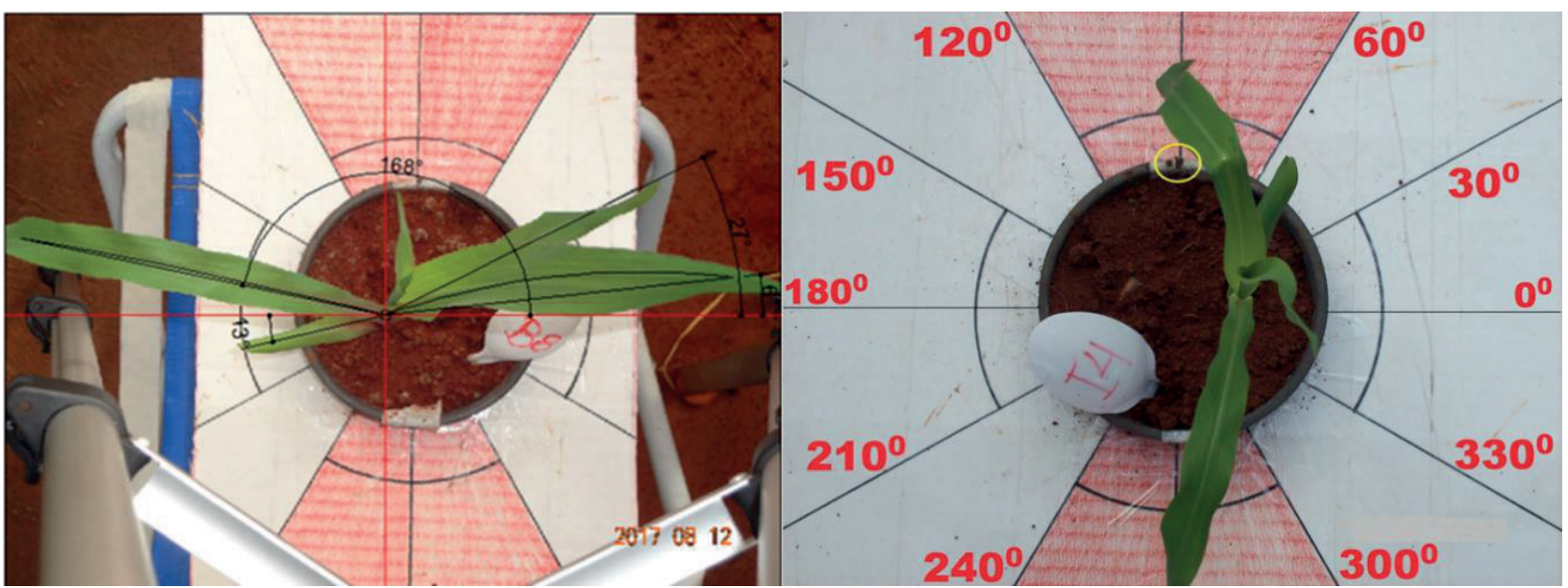

Figure 3. Angle stratification according to orientation: perpendicular, diagonal and parallel.

Orientation was stratified as perpendicular, diagonal or parallel, using the signaled marking on the pot as reference, as proposed by Torres et al. (2011):

(1) Leaf angles between $0^{\circ}$ and $30^{\circ}$ : angles with greater approximation in the perpendicular direction to the reference mark. This orientation may be favorable depending on the position of the seed relative to the reference marking on the pot and may minimize leaf overlap and shading in the crop canopy;

(2) Leaf angles between $31^{\circ}$ and $59^{\circ}$ : angles with leaf orientation in the diagonal direction to the reference mark. In the more advanced vegetative stages of the crop, they may result in leaf overlap and self-shading, indicating that they are not favorable;

(3) Leaf angles between $60^{\circ}$ and $90^{\circ}$ : angles with greater approximation of the leaves in the parallel direction to the reference mark. This orientation may, however, be favorable depending on the position of the seed relative to the reference marking and minimize leaf overlap and shading as long as the seed is in an adequate position relative to the reference mark on the pot.

The collected data were transformed by the Box-Cox power transformation technique to adjust the assumptions of normality and homogeneity of variance and subsequently subjected to the $\mathrm{F}$ test of analysis of variance (ANOVA). The means of leaf angles in relation to the horizontal plane were compared by Tukey's test at the 5\% significance level. Statistical analyses were performed using the "RStudio" package (R Development Core Team, 2014).

\section{Results and Discussion}

To evaluate seed positioning in the planting furrow on leaf orientation and plant architecture in the horizontal plane, analyses of variance were performed with the values transformed due to non-normality of the original data $(p=0.01726)$ and heterogeneity of variances $(p=0.04431)$. The $\mathrm{F}$ test resulted significant, with $\mathrm{p}=0.008827$. When the degrees of freedom of the treatments were decomposed, according to the factorial arrangement, the effects of seed type $(\mathrm{p}=0.4907)$ and its interaction with seed positioning in the planting furrow ( $p=0.7811$ ) were not significant, revealing the sole importance of the effect of positioning $(\mathrm{p}<0.001)$.

The means found for leaf orientation angles (Table 2), measured during the V3 vegetative stage at the third fully expanded leaf, suggested the formation of a cluster for treatments Df 
(homologous to Dr) and $\mathrm{Cr}$, approximating parallel orientation, with mean angles of $67.375^{\circ}, 64.000^{\circ}$ and $61.000^{\circ}$, respectively. The $\mathrm{Bf}$ and $\mathrm{Br}$ treatments, in turn, exhibited orientations approximating the perpendicular type, with respective mean angles of $13.174^{\circ}$ and $15.143^{\circ}$.

Table 2

Means and standard deviations for maize leaf orientation angle in response to controlled seed positioning. Treatments: Af (flat seed) and Ar (round seed) - horizontal position lying on the side and tip pointing toward the marking on the border of the pot; $\mathrm{Bf}$ (flat seed) and $\mathrm{Br}$ (round seed) - vertical position, tip pointing down toward the bottom of the pot; $\mathrm{Cf}$ (flat seed) and $\mathrm{Cr}$ (round seed) - vertical position and tip pointing toward soil surface; Df (flat seed) and Dr (round seed) - horizontal position lying with the dorsal face on the soil and tip pointing toward the marking on the pot; Ef (flat seed) and $\mathrm{Er}$ (round seed) - horizontal position lying with the ventral face on the soil and tip pointing toward the marking on the pot

\begin{tabular}{ccc}
\hline Treatment $^{(2)}$ & Mean & Standard deviation \\
\hline Af & $27.125 \mathrm{ab}$ & 16.617 \\
Bf & $13.714 \mathrm{~b}$ & 8.160 \\
Cf & $41.625 \mathrm{ab}$ & 36.091 \\
Df & $67.375 \mathrm{a}$ & 16.124 \\
Ef & $45.000 \mathrm{ab}$ & 24.553 \\
Ar & $24.000 \mathrm{ab}$ & 16.388 \\
Br & $15.143 \mathrm{~b}$ & 16.395 \\
$\mathrm{Cr}$ & $61.000 \mathrm{a}$ & 27.558 \\
Dr & $64.000 \mathrm{a}$ & 15.222 \\
Er & $49.875 \mathrm{ab}$ & 24.620 \\
\hline
\end{tabular}

*Tukey's test with transformed data. Means followed by different letters differ from each other according to Tukey's test at the $5 \%$ probability level.

The $\mathrm{Bf}$ and $\mathrm{Br}$ treatments showed significant differences in relation to Df, Dr and Cr. The B treatment (flat and round) exhibited a higher percentage of perpendicular leaf orientation (100\% and $85.7 \%$, respectively) in relation to the reference mark made on the border of the pot, which was reinforced by the lower percentages of diagonal orientation $(0 \%$ and $14.3 \%)$ and the nonmanifestation of parallel orientation (Figure 4), suggesting a lower possibility of leaf overlap. In the study led by Toler et al. (1999), perpendicular orientation of the maize leaf to the sowing row was attained when the seed was laid in the soil with the tip pointing down and the face where the embryo is seen directed toward the inter-row space. Experiments investigating the perpendicular orientation of the maize leaf suggest that shading can be prevented (Toler et al., 1999; Torres et al., 2011) with the use of hybrids characterized by smaller size and upright leaves, which enable plant densification (Stacciarini et al., 2010). The adoption of reduced spacing can contribute to a better initial development of the crop and produce a canopy more efficient in intercepting PAR, which in turn would result in increased grain yield (Farinelli, Penariol, \& Fornasieri, 2012). 


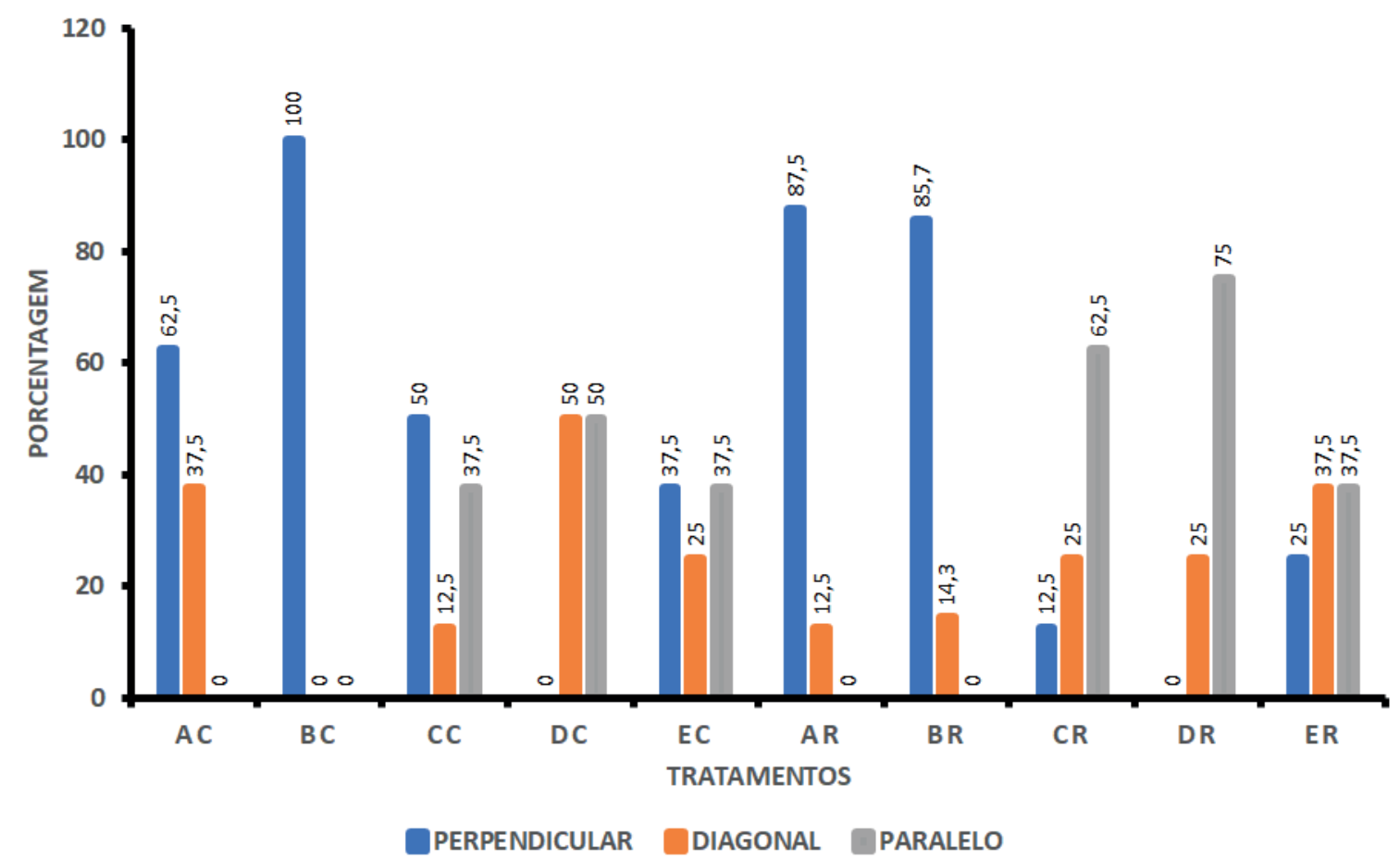

Figure 4. Leaf orientation percentages in the treatments in the horizontal plane in response to controlled seed positioning. Flat (f) and round (r) seed treatments: Af and $\mathrm{Ar}$ - horizontal position lying on the side and tip pointing toward the marking on the border of the pot; $\mathrm{Bf}$ and $\mathrm{Br}$ - vertical position, tip pointing down toward the bottom of the pot; $\mathrm{Cf}$ and $\mathrm{Cr}$ - vertical position and tip pointing toward soil surface; $\mathrm{Df}$ and $\mathrm{Dr}$ - horizontal position lying with the dorsal face on the soil and tip pointing toward the marking on the pot; $\mathrm{Ef}$ and $\mathrm{Er}$ - horizontal position lying with the ventral face on the soil and tip pointing toward the marking on the pot.

A greater frequency of parallel orientation was observed in the Df and Dr treatments $(50 \%$ and 75\%), which did not show leaves in the perpendicular orientation (Figure 4). These results may be attributed to the seed positioning adopted at sowing and the directional growth (tropism) of the embryo axis formed by the radicle, mesocotyl and hypocotyl, including the plumule, during the seedling germination and emergence processes (Taiz et al., 2017). The embryo emerges along the depth direction (length) of the maize seed, following the natural anatomy of the maize plant, with leaves from one side practically identical to the other side, in a $180^{\circ}$ plane (Torres et al., 2011).

The treatments with the seed positioned vertically pointing down toward the bottom of the pot $(\mathrm{Bf}$ flat; $\mathrm{Br}$ - round) (Figure 5B) and horizontally with the dorsal face on the soil (Df - flat; Dr - round) (Figure 5A) may provide a favorable orientation, that is, perpendicularly to the reference line, as long as the seed face that contains the embryo remains positioned in the perpendicular direction, following natural embryo emergence. In the specific case of treatments Df and Dr, with parallel orientation, in Figure 5A, to transform it into a perpendicular orientation as in treatment $\mathrm{B}$ in Figure $5 \mathrm{~B}$, the seed tip should be placed perpendicularly to the imaginary line determined by the marking on the border of the pot. An experiment conducted by Torres et al. (2011) demonstrated that it is possible to position the seed in an oriented manner in the planting furrow and obtain a plant architecture with leaf angles in the horizontal plane perpendicular or parallel to the sown row. 

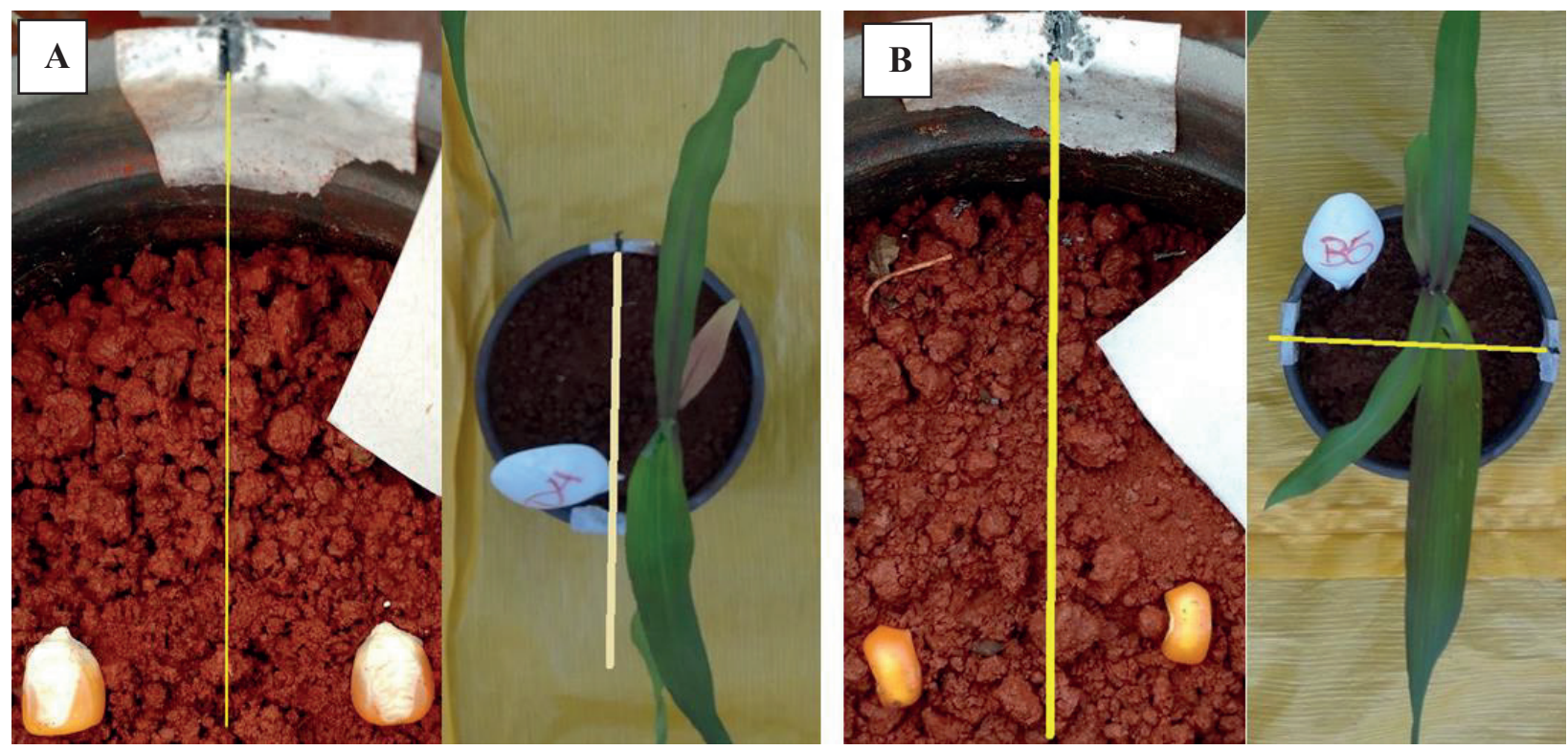

Figure 5. Treatment D: seed lying horizontally, dorsal face touching the soil and tip pointing toward the marking on the border of the pot, resulting in a parallel orientation of the maize plant (A). To achieve the orientation perpendicular to the imaginary line by the reference marking on the border of the pot, the seed embryo axis should be placed in the perpendicular direction. Treatment B: seed positioned vertically and embryo face perpendicularly to the reference line, resulting in leaves in perpendicular orientation (B).

The $\mathrm{Cr}$ treatment was significantly different from the $\mathrm{Bf}$ and $\mathrm{Br}$ treatments. Additionally, it exhibited the three variations of orientation (perpendicular, diagonal and parallel) at the same time (Figure 4), as did the $\mathrm{Cf}$, Er and Ef treatments. This is unfavorable for a single treatment due to the higher possibility of plants having a random architecture and there possibly being greeter intraspecific competition and less efficiency in PAR interception during the maize growth period (Loomis \& Amthor, 1999; Toler et al., 1999). A study conducted by Torres et al. (2011) on the oriented placement of the seed in the vertical position, parallel to the sowing row and with the radicle pointing down, resulted in the frequency distribution of $90 \%$ of plants with a leaf angle between $60^{\circ}$ and $90^{\circ}$, characterizing an orientation perpendicular to a referential " $\mathrm{X}$ " axis, representing an orientation line. The seed positioned lying down, with the embryo facing up and parallel to the row, pointing left and right, resulted in $80 \%$ of the leaf angles between $0^{\circ}$ and $30^{\circ}$ relative to a referential " $X$ " axis. In this case, the results suggest the possibility of altering the plant leaf orientation to a higher favorable percentage in both the rows and inter-rows sown according to seed positioning.

Although the method of measuring, classifying and stratifying seed positioning adopted in this study showed some differences compared to the method employed by Torres et al. (2011), the results were similar. The average angles of the $\mathrm{Bf}$ and $\mathrm{Br}$ and Df and Dr treatments fit the ranges of $0^{\circ} \sim 30^{\circ}$ and $60^{\circ} \sim 90^{\circ}$, respectively, suggesting that, for those treatments, seed positioning and the conceptual stratification of angle category are irrelevant, since both treatments can produce leaves in the perpendicular orientation. Torres et al. (2011) sowed seeds lying with the embryo face up, parallel to the sowing row, pointing left and right, and obtained $80 \%$ of the leaf angles between $0^{\circ}$ and $30^{\circ}$ in the first experiment (E1). In the second experiment (E2), with alterations made in seed positioning, now perpendicular to the sowing row, the obtained percentages were $77.8 \%$ to $90 \%$ of the plants with 
a leaf angle between $60^{\circ}$ and $90^{\circ}$, indicating that leaves oriented perpendicularly to the sowing row in the horizontal plane would promote an increase in light interception and in yield.

The Af, Ar, Cf, Ef and Er treatments did not differ significantly from the other treatments. Although seed positioning in the Af and $\mathrm{Ar}$ treatments induced an important deformation of the mesocotyl during plant emergence, as shown in Figure 6, they resulted in a high percentage of the perpendicular orientation $(62.5 \%$ and $87.5 \%$, respectively) (Figure 4). In the studies led by Torres et al. (2011), with similar treatments, in Experiment 1 , the authors obtained $66.7 \%$ and $70.0 \%$ of the plants with leaves orientated at angles between $60^{\circ}$ and $90{ }^{\circ} \mathrm{C}$. In Experiment 2, in turn, this angle range was found in $44.4 \%$ and $80.0 \%$ of the plants. These results suggest instability in the development of perpendicular orientation of the maize leaf due to the range of percentages obtained for this seed position, thus warranting further studies.

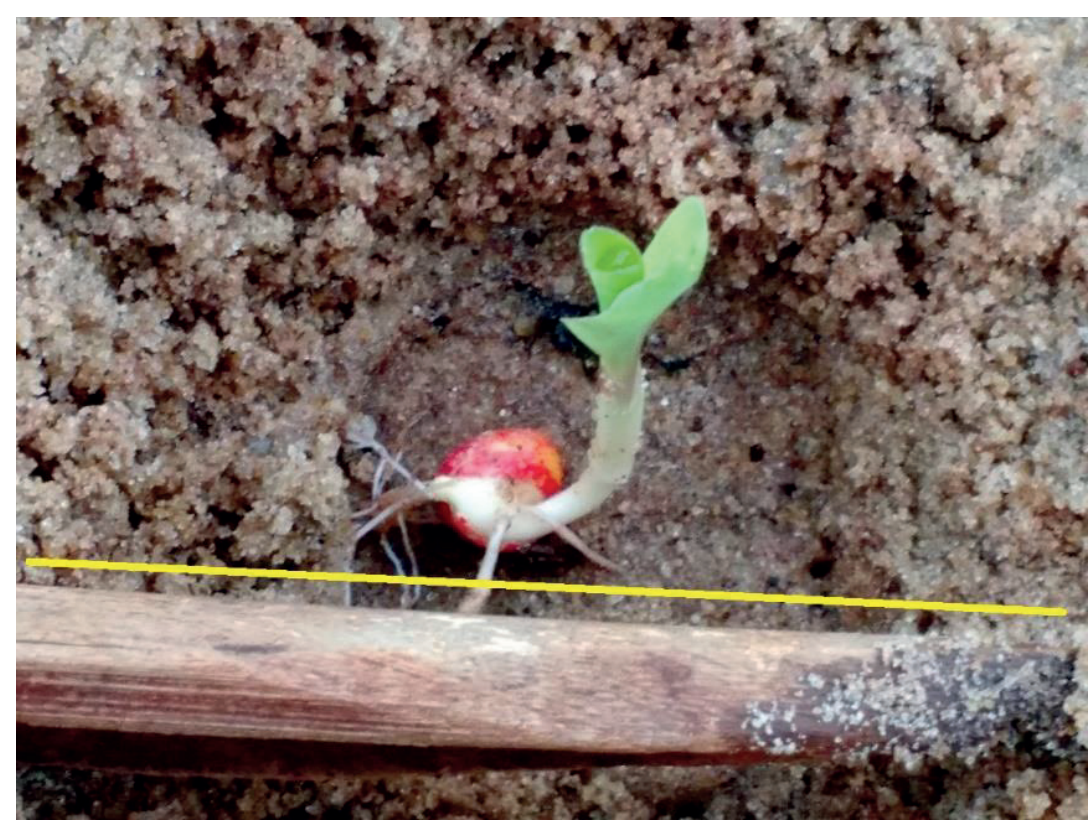

Figure 6. Seed positioned lying on the side; upon embryo emergence, the mesocotyl in sand substrate starts twisting and deforming.

The obtained results, with orderly organized plant and leaf architecture, encourage the development of new research on plant densification to allow sowing in large populations aiming at increased grain yield or maintenance of high yields in reduced plant populations, as demonstrated in studies that investigated grain yield with reductions in inter-row spacing and plant density (Farinelli, et al., 2012; Fumagalli et al., 2017).

\section{Conclusions}

Flat and round maize seeds positioned vertically, with the face containing the embryo directed toward the inter-row space, and horizontally, with the embryo facing the soil surface, will produce a plant oriented perpendicularly to the sowing row. 


\section{Acknowledgments}

The authors thank the Coordination for the Improvement of Higher Education Personnel (CAPES) for the fellowship grant with financial support for the development research studies.

\section{References}

Argenta, G., Silva, P. R. F., \& Sangoi, L. (2001). Arranjo de plantas em milho: análise do estado-da-arte. Ciência Rural, 31(6), 1075-1084. doi: 10.1590/ S0103-84782001000600027

Autodesk (2014). Autocad 2014. Retrieved from https:// knowledge.autodesk.com/pt-br/support/autocad/ troubleshooting/caas/CloudHelp/cloudhelp/PTB/ Autodesk-Installation/files/GUID-CD9E439F38F4-4FC9-A2A7-3C5E4EEA6B9D-htm.html

Castro, P. R. C., Kluge, R. A., \& Sestari, I. (2008). Fisiologia de cultivos. Em manual de fisiologia vegetal. São Paulo: Editora Agronômica Ceres.

Costa, K. D. S., Carvalho, I. D. E., Ferreira, P. V., Santos, P. R., Souza, E. G. F., \& Sousa, T. P. (2015). Avaliação de genótipos de milho em diferentes densidades populacionais. Agropecuária Cientifica no Semiárido, 11(3), 18-30. doi: 10.30969/acsa. v11i3.602

Farinelli, R., Penariol, F. G., \& Fornasieri, D., Fo . (2012) Características agronômicas e produtividade de cultivares de milho em diferentes espaçamentos entre linhas e densidades populacionais. Cientifica, 40(1), 21-27. doi: 10.15361/1984-5529.2012v40n $1 \mathrm{p} 21+-+27$

Felipe, C. R. P., Duarte, J. B., \& Camarano, L. F. (2010) Estratificação ambiental para avaliação e recomendação de variedades de milho no estado de Goiás. Pesquisa Agropecuária Tropical, 40(2), 186199. doi: 10.5216/pat.v40i2.6158

Fortin, M. C., \& Pierce, F. J. (1996). Leaf azimuth in strip-intercropped corn. Agronomy Journal, 88(1), 6-9. doi: 10.2134/agronj1996.00021962008800010 $002 \mathrm{x}$

Fumagalli, M., Machado, R. A. F., Fiorini, I. V. A., Pereira, C. S., Pires, L. P. M., \& Pereira, H. D. (2017). Desempenho produtivo do milho híbrido simples em função de espaçamento entre fileiras e populações de plantas. Revista Brasileira de Milho e Sorgo, 16(3), 426-439. doi: 10.18512/1980-6477/ rbms. v16n3p426-439
Girardin, P. (1992). Leaf azimuth in maize canopies. European Journal Agronomy, 1(2), 91-97. doi: 10.1016/S1161-0301(14)80006-3

Kappes, C., Andrade, J. A. C., Arf, O., Oliveira, A. C. de, Arf, M. V., \& Ferreira, J. P. (2010). Desempenho de híbridos de milho em diferentes arranjos espaciais de plantas. Bragantia, 2(70), 334-343. doi: 10.1590/ S0006-87052011000200012

Loomis, R. S., \& Amthor, J. S. (1999). Yield potential, plant assimilatory capacity, and metabolic efficiencies. Crop Science, 39(6), 1584-1596. doi:10.2135/cropsci1999.3961584x

Loomis, R. S., \& Williams, W. A. (1969). Productivity and the morphology of crop stands: patterns with leaves. [S. 1.]: Agronomy-Faculty Publications.

Ottman, M. J., \& Welch, L. F. (1989). Planting patterns and radiation interception, plant nutrient concentration, and yield in corn. Agronomy Journal, 81(2), 167-174. doi: 10.2134/agronj1989.00021962008100020006x

Pereira, L. B., Machado, D. S., Alves, D. C., Fº, Brondani, I. L., Silva, V. S. da, Argenta, F. M., M. A. F. de, \& Borchate, D. (2017). Características agronômicas da planta e produtividade da silagem e grãos de milho submetido a diferentes arranjos populacionais. Magistra, 29(1), 18-27.

Petter, F. A., Silva, J. A. da, Zuffo, A. M., Andrade, F. R., Pacheco, L. P., \& Almeida, F. A. (2016). Elevada densidade de semeadura aumenta a produtividade da soja? Respostas da radiação fotossinteticamente ativa. Bragantia, 75(2), 173-183. doi: 10.1590/16784499.447

R Development Core Team (2014). A language and environment for statistical computing. Vienna, Austria: R Foundation for Statistical Computing. Retrieved from URL http://www.R-project.org/

Regitano-D'Arce, M. A. B., Spoto, M. H. F., \& Castellucci, A. C. L. (2015). Processamento e industrialização do milho para alimentação humana. Visão agrícola. Piracicaba: Pyxis Editorial e Comunicação, Piracicaba, ano 9.

Ritchie, S., \& Hanway, J. J. (1989). How a corn plant develops. (Special Report n. 48). Ames: Iowa State University of Science and Technology, Cooperative Extension Service.

Sangoi, L., Ender, M., Guidolin, A F., Almeida, M. L. D., \& Heberle, P. C. (2001). Influence of row spacing reduction on maize grain yield in regions with a short summer. Pesquisa Agropecuária Brasileira, 36(6), 861-869. doi: 10.1590/S0100-204X2001000600003 
Sangoi, L., Schweitzer, C., Silva, P. R. F. da, Schmitt, A., Vargas, V. P., Casa, R. T., \& Souza, C. A. da. (2011). Perfilhamento, área foliar e produtividade do milho sob diferentes arranjos espaciais. Pesquisa Agropecuária Brasileira, 46(6), 609-616. doi: 10.1590/S0100-204X2011000600006

Sangoi, L., Silva, P. R. F. da, \& Argenta, G. (2010a). Estratégia de manejo do arranjo de plantas para aumentar o rendimento de grãos do milho. Lages: Graphel.

Sologuren, L. (2015). Demanda mundial cresce e Brasil tem espaço para expandir produção. Visão agrícola. Piracicaba: Pyxis Editorial e Comunicação, Piracicaba, ano 9.

Stacciarini, T. C. V., Castro, P. H. C. de, Borges, M. A., Guerin, H. F., Moraes, P. A. C., \& Gotardo, M. (2010). Avaliação de caracteres agronômicos da cultura do milho mediante a redução do espaçamento entre linhas e aumento da densidade populacional. Revista Ceres, 57(4), 516-519. doi: 10.1590/S0034737X2010000400012
Taiz, L., Moller, E. Z. I. M., \& Murphy, A. (2017). Fisiologia e desenvolvimento vegetal. Porto Alegre: Artmed Editora Ltda.

Toler, J. E., Murdock, E. C., Stapleton, G. S., \& Wallace, S. U. (1999). Corn leaf orientation effects on light interception, intraspecific competition, and grain yields. Journal of Production Agriculture, 12(3), 396-399. doi: 10.2134/jpa1999.0396

Torres, G., Vossenkemper J., Raun W., \& Taylor, R. (2011). Maize (Zea mays) leaf angle and emergence as affected by seed orientation at planting. Experimental Agriculture, 47(4), 579-592. doi: 10.1017/ S001447971100038X

Uate, J. V., Von Pinho, R. G., Cancellier. L. L., Camilo, A., \& Bernardo, L. A. Y., Jr. (2015). Épocas de semeadura e distribuição espacial de plantas na produção de milho. Revista Brasileira de Milho e Sorgo, 14(3), 346-357. doi: 10.18512//1980-6477/ rbms.v14n3p346-357 